\title{
Assessment of selected nutrients and toxic metals in fruits, soils and irrigation waters of Awara Melka and Nura Era farms, Ethiopia
}

\author{
Shambel G. Yami ${ }^{1}$, Bhagwan Singh Chandravanshi ${ }^{*}$, Taddese Wondimu ${ }^{1,2}$ and Cherinet Abuye ${ }^{3}$
}

\begin{abstract}
The objective of the present study was to determine the levels of essential nutrients ( $\mathrm{Na}, \mathrm{K}, \mathrm{Ca}, \mathrm{Mg}$, $\mathrm{Fe}, \mathrm{Cu}, \mathrm{Zn}, \mathrm{Mn}$ ) and toxic metals ( $\mathrm{Pb}$ and $\mathrm{Cd}$ ) in selected varieties of fruits (banana, grape, guava, mandarin and orange), farmland soils and irrigation waters to assess nutritional impact on health. The freeze dried fruits were digested using $\mathrm{HNO}_{3}$ and $\mathrm{HClO}_{4}$ and the levels of the elements determined using flame atomic absorption spectrometer. The highest amount of $\mathrm{K}$ (3480) and $\mathrm{Mg}$ (281) and the lowest amount of $\mathrm{Na}(6.4)$ and $\mathrm{Ca}(75) \mathrm{\mu g} / \mathrm{g}$ were obtained in banana compared to other analyzed fruits. Cd was detected in guava $(0.2 \mu \mathrm{g} / \mathrm{g})$, orange $(0.3 \mu \mathrm{g} / \mathrm{g})$ and mandarin $(0.1 \mu \mathrm{g} / \mathrm{g})$, but not detected in banana and grape. Pb was not detected in all the fruits. Appreciable amount of total ascorbic acid was found in guava $(1170 \mu \mathrm{g} / \mathrm{g})$ compared to that of other fruits. Furthermore, farmland soils and irrigation waters were analyzed for the selected metals and physico-chemical properties of soils including $\mathrm{pH}$, electrical conductivity, cation exchange capacity, texture and available phosphorus determined to elucidate factors controlling the availability of metals in fruits. Applying statistical packages, analysis of variances and Pearson correlation, links between metal levels in fruits and those in soil and water samples were evaluated.
\end{abstract}

Keywords: Banana, Grape, Guava, Mandarin, Orange, Fruits, Minerals, Toxic metals, Ascorbic acid, Farm soils, Irrigation waters

\section{Background}

Fruits are natural staple food for humans. They contain substantial quantities of essential nutrients in good proportion (Elbagermi et al. 2012). Other vital components in fresh fruits such as vitamin $\mathrm{C}$, carotenoids, minerals and dietary fiber are vital requisites to body's optimum immunity functions (Maggini et al. 2010). In addition, they contain water, calcium, iron, for the maintenance of health and the prevention of various diseases (D'Mello 2003). Consumption of fruits on a regular basis is critical in providing health promoting nutrients to the human body.

\footnotetext{
*Correspondence: bscv2006@yahoo.com

1 Department of Chemistry, College of Natural Sciences, Addis Ababa University, P. O. Box 1176, Addis Ababa, Ethiopia

Full list of author information is available at the end of the article
}

Studies reporting the mineral contents of fruits and vegetables have appeared in the literature in an attempt to assess the nutritional benefits and potential risks arising from the consumption of fruits. Kalagbor et al. (2014) have studied the levels of heavy metals in four fruits from Nigeria. Basha et al. (2014) have reported trace metals in vegetables and fruits cultivated in India. Igwegbe et al. (2013) have reported a survey of heavy metal contents of selected fruit and vegetable crops in Nigeria. Elbagermi et al. (2012) have reported heavy metal content in fruits and vegetables in Libya. Akhtar et al. (2010) have studied heavy metal content of mangoes cultivated in different regions of Pakistan. Ang and Ng (2000) have reported trace element concentration in mango, seedless guava and papaya grown in Malaysia. Mausi et al. (2014) have conducted study on the assessment of selected heavy metal concentrations in selected fresh fruits in Kenya. 
Mineral and nutritional analysis has been reported on apple, avocado, apricot, and banana collected from Tigray, Gonder, Wello, Arsi, Harar and Sidamo (Ethiopia) and average data for each fruit have been reported (EHNRI 1998). However, variations of nutrient composition of fruits on characteristics of the land, climate, cultivation conditions, and stage of maturation, and the role of fertilization and irrigation water have been overlooked. In addition, only few fruits were analyzed even though the composition varies within species.

In recent years, growing interest has been shown in the levels of metals in vegetables and other food stuffs, farmland soils and irrigation waters in Ethiopia. Yemane et al. (2008) studied the levels of essential and non-essential metals in tea leaves and soils of Wushwush farms. Nigussie et al. (2010) established correlation among trace metals in fish, sediment and water samples of lakes Awassa and Ziway. Atlabachew et al. (2011) profiled major, minor and toxic metals in soil and khat cultivars. Weldegebriel et al. (2012) determined the levels of metals in vegetables grown in soils irrigated with river water in Addis Ababa. The study by Kitata and Chandravanshi (2012) reports the levels of major and trace metals in onion and irrigation water around Meki Town and Lake Ziway. More recently, the levels of essential and non-essential metals in ginger (Wagesho and Chandravanshi 2015) and in seeds of cardamom, also locally known as korerima, cultivated in Ethiopia were reported (Mekassa and Chandravanshi 2015).

There are variations in nutrient composition among and within the existing species of fruits depending on the characteristics of the land, climate, cultivation conditions and composition of irrigation water. The United Nations Organization for Food and Agriculture has recommended that food composition charts should be prepared for food produced and consumed locally. In Ethiopia, such data are not readily available. Therefore, the objective of this study was to determine the extent of accumulation of essential nutrients $(\mathrm{Na}, \mathrm{K}, \mathrm{Ca}, \mathrm{Mg}$, $\mathrm{Fe}, \mathrm{Cu}, \mathrm{Zn}$, and $\mathrm{Mn}$ ), toxic metals ( $\mathrm{Pb}$ and $\mathrm{Cd}$ ), moisture content and total ascorbic acid in fruits (banana, grape, guava, mandarin and orange) produced in Awara Melka and Nura Era Farms, Ethiopia. The soils and irrigation waters were also analyzed for metals to estimate relationship between the levels of metals in fruits with that of soil and irrigation water.

\section{Methods}

\section{Equipment}

Freeze dryer (Freeze dry-3, Labconco, Kentucky, USA) was used for drying fruit samples to constant mass. A blender (Super Blender Mill Grater 3, France) was used to homogenize fruit samples. A digestion apparatus consisting of $100 \mathrm{~mL}$ round or flat bottom flask fitted with condenser and a hotplate was used for decomposing the sample matrix. A flame atomic absorption spectrometer (Buck Scientific Model 210VGP AAS, East Norwalk, USA) was used for determining the concentrations of metals in fruit, soil and water samples. S2000 Lightwave Spectrophotometer (Cambrige, UK) equipped with UV/ VIS diode array detector was used for the determination of total ascorbic acid. Inolab $\mathrm{pH} / \mathrm{ION}$ Level $2 \mathrm{pH}$ meter (WTW, Weilheim, Germany) was used for the measurement of the soil $\mathrm{pH}$. Thermo Orion Conductivity meter Model 145 (Thermo Electron Corporation, Midrand, USA) was used for the measurement of electrical conductivity of soil samples.

\section{Reagents}

Deionized water was used throughout the experiments for all dilutions and rinsing purposes. $70 \% \mathrm{HNO}_{3}$ (Spectrosol ${ }^{\circledR}$, England), $70 \% \mathrm{HClO}_{4}$ (Aldrich, A.C.S. Reagent, Germany) and $37 \% \mathrm{HCl}$ (Riedel-deHaen, Chem Pure, Germany) were used as received for the digestion of fruit and soil samples. Stock standard solutions of the metals (1000 mg/L) calibration standards (Buck Scientific, USA), prepared as nitrates for each element in $2 \% \mathrm{HNO}_{3}$, were used for the preparation of calibration curves for the determination of metals in the samples. $98.5 \%$ trichloroacetic acid (Hopkin and Williams, A.C.S. Reagent, England), meta-phosphoric acid (BDH, G.R., England), 2,4-DNPH (Schiapparelli, A.R., Italy), 95-97 \% $\mathrm{H}_{2} \mathrm{SO}_{4}$ (Merck, Germany), 99.5 \% thiourea (Merck, G.R., Germany), $99.5 \% \mathrm{Br}_{2}$ (Merck, A.R., Germany) and $99.7 \%$ L-ascorbic acid standard (BDH, Anala ${ }^{\circledR}$, England) were used for the determination of vitamin $\mathrm{C}$ in the fruit samples.

\section{Fruits sampling and pretreatment}

The selection of fruit type among the available varieties was based on the largest productivity and high consumption of the fruit by the society. The largest citrus orchard (about 1000 ha) in Ethiopia is found in Nura Era Farm (Seifu 2003). Banana is not produced in Nura Era farm. Hence unripe banana (Musa cavendish) was collected from Awara Melka Farm and allowed to ripen in the laboratory according to the procedure followed by the farm (providing heat by covering the fruit with sacks and plastics). White grape, guava (unknown variety), mandarin (orlando variety), and orange (pineapple variety) of similar degree of maturity were collected randomly from different plants grown in Nura Era Farm. All the fruits were fully matured and first grade according to the farms' criteria. The sampling sites are shown in Fig. 1.

The fruits except banana were placed in ice-box to keep them as fresh as possible with polyethylene sheet between 


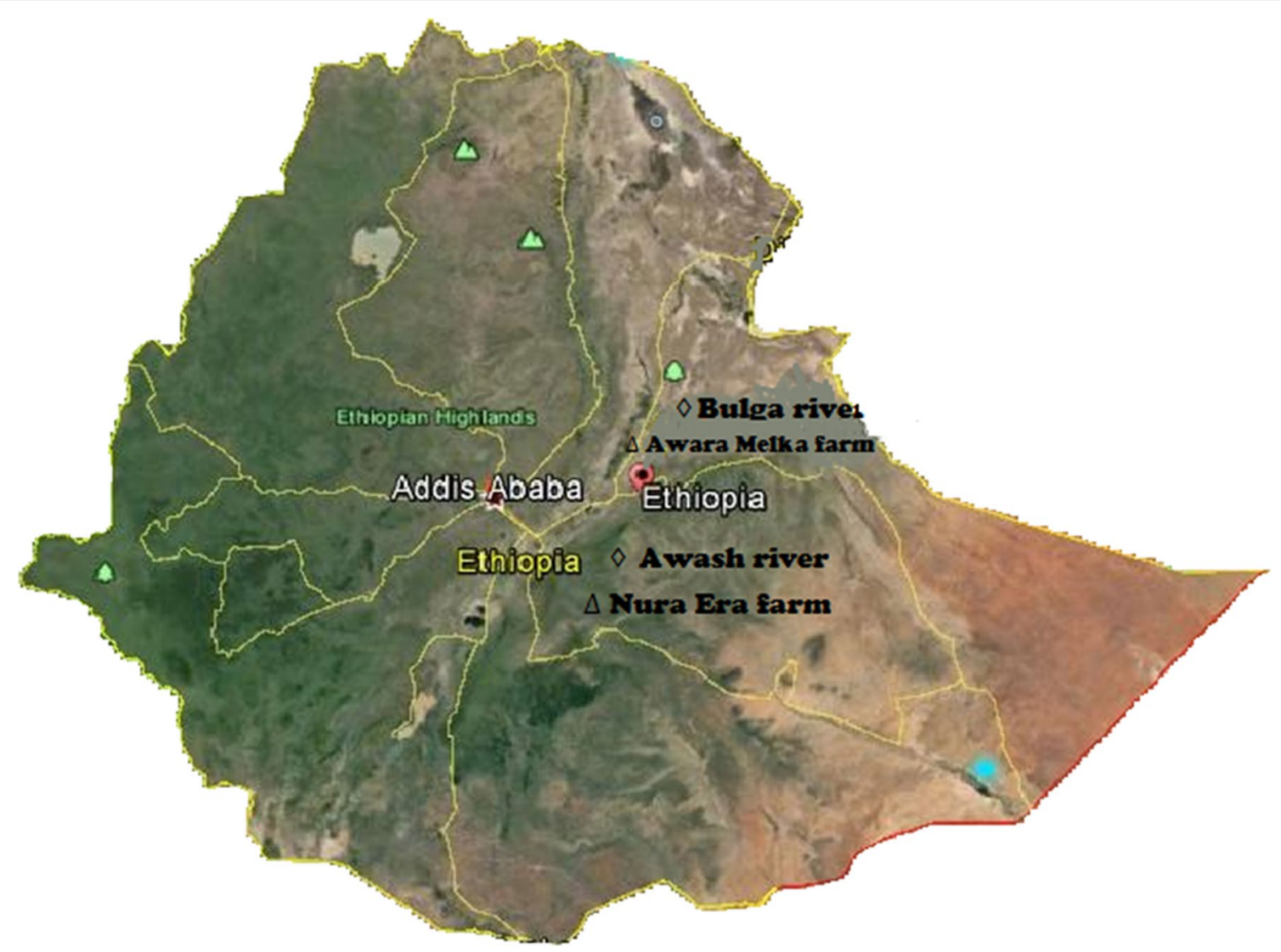

Fig. 1 Map of Ethiopia showing the sampling sites

each fruits to minimize diffusion through contact. The fruits were transported to the laboratory within 1 day after collection. Surface contaminants of the fruits were washed with tap water, rinsed with deionized water and dried with tissue paper (Storey and Treeby 2000). Some portions of the fruits were kept at $-20{ }^{\circ} \mathrm{C}$ until analysis for ascorbic acid without peeling the fruits. From the remaining fruits, each fruit was dissected into quarters along the equatorial plane (Townshend 1995) with plastic knife. A quarter or a representative sub-sample of each fruit of the same species was collected and peeled. Seeds and large particles of cellular materials were removed to represent the edible portion (Miller-Ihli 1996; Simpkins et al. 2000). The samples were homogenized in a blender and freeze dried until constant masses were obtained. The dry samples were stored in polyethylene bags until the time of analysis.

\section{Soil sampling and pretreatment}

Two soil samples from Awara Melka Farm (one from banana land and one from orange and mandarin land) and two soil samples from Nura Era Farm (one from grape land and one from guava land) were collected.
Sampling points for soil samples were selected based on an imaginary zigzag line/pattern (Tan 1996). About 500 g of soil from each of the four composite samples was taken and thoroughly mixed in the laboratory. The soil sample was air dried in the laboratory, ground using mortar and pestle, sieved through $0.090 \mathrm{~mm}$ sieve and then stored in plastic bags until analysis.

\section{Water sampling and pretreatment}

Water samples were collected from Bulga and Awash Rivers that are used for irrigation by Awara Melka and Nura Era Farms, respectively. These two rivers are approximately $1 \mathrm{~km}$ from the respective farms. The samples were collected at inversion points of the main channel from the rivers and from the channels (four samples from Awara Melka Farm and nine from Nura Era Farm at the inversion from sub-main irrigation channel to each block of fruit lands) that feed the selected fruits. In all cases the water samples were taken by placing the mouth of polyethylene containers (nitric acid cleaned) approximately $2 \mathrm{~cm}$ below the surface of the water. The water samples were brought to the laboratory and then centrifuged to remove the suspended particles, filtered, and preserved 
with $2 \mathrm{~mL}$ of $10 \% \mathrm{HNO}_{3}$ per $100 \mathrm{~mL}$ of water and stored in a refrigerator (Fifield and Haines 1997).

\section{Digestion of fruits for metal determination}

The optimal procedure was developed with banana and orange samples, expecting that the citrus fruits have similarity with that of orange. Different wet-digestion methods were tested to select optimum procedure. The procedure was adopted from that used by Clemson University with some modification (Clemson University 2000). The optimization was based on production of clear solution, shorter digestion time and minimum reagent consumption. The optimum procedure was found to be the one involving refluxing $0.25 \mathrm{~g}$ of fruit sample in a $100 \mathrm{~mL}$ round bottomed flak with $4 \mathrm{~mL}$ concentrated $\mathrm{HNO}_{3}$ and $4 \mathrm{~mL}$ of concentrated $\mathrm{HClO}_{4}$ for $125 \mathrm{~min}$ at $240{ }^{\circ} \mathrm{C}$. The cooled digest and its washings were transferred into a $25 \mathrm{~mL}$ volumetric flask and diluted to the mark with deionized water. The digests were prepared in triplicates for each sample.

\section{Extraction of metal from soil samples}

Conventional aqua regia digestion was applied (Chen and Ma 2001) using $100 \mathrm{~mL}$ glass Erlenmeyer flask. Wellmixed soil sample weighing $0.5000 \mathrm{~g}$ was digested with $12 \mathrm{~mL}$ of aqua regia on a boiling water bath for $3 \mathrm{~h}$. The mixture was cooled, diluted with $20 \mathrm{~mL}$ of $2 \%(\mathrm{v} / \mathrm{v})$ nitric acid and transferred into a $100 \mathrm{~mL}$ volumetric flask after filtering through Whatman No. 1 filter paper and diluted to $100 \mathrm{~mL}$ with deionized water.

\section{Determination of metals in fruits, soils and water samples} The concentrations of $\mathrm{Ca}, \mathrm{Mg}, \mathrm{Fe}, \mathrm{Mn}, \mathrm{Cu}, \mathrm{Zn}, \mathrm{Pb}$ and $\mathrm{Cd}$ in the digested fruit and soil samples, and pretreated water samples were determined using flame atomic absorption spectrometer. An appropriate dilution was made with $0.5 \%(\mathrm{w} / \mathrm{w}) \mathrm{Sr}\left(\mathrm{NO}_{3}\right)_{2}$ to overcome ionic interference during the determination of $\mathrm{Ca}$ and $\mathrm{Mg}$ (Paul and Shaha 2004). However the concentrations of $\mathrm{Na}$ and $\mathrm{K}$ were determined in emission mode of FAAS with optimum instrumental condition (Paul and Shaha 2004). Metal concentrations were determined in the digested solutions using external calibration curves.

\section{Recovery of metals in spiked fruit samples}

The validity of optimized digestion procedure for fruits was checked by carrying out spiking test and evaluating percent recovery. This involved spiking of fruit samples with standard solutions of metals (Maroto et al. 2001). To do this, a fixed volume of a mixture of metal standards was added to a mixture of $0.25 \mathrm{~g}$ of fruit and then the optimized procedure for fruit digestion was carried out on this mixture. The digests were prepared in triplicates. The concentrations of the metals were determined with FAAS using external calibration graph. The percentage recoveries were found within acceptable range $(100 \pm 10)$ for all the elements, except $\mathrm{Mg}$, for which $89 \%$ recovery was obtained. These findings demonstrated suitability of the digestion procedure developed.

\section{Recovery of metals in spiked soil samples}

To check the validity of the optimized digestion procedure for the determination of metals in soil samples, spiking tests were conducted. To do this, a fixed volume of a mixture of metal standards was added to a mixture of $0.5000 \mathrm{~g}$ of soil and $12 \mathrm{~mL}$ aqua regia. The selected digestion procedure was carried out on this mixture as it was done for the unspiked sample. The digests were prepared in triplicates. The concentrations of the metals were determined with FAAS using external calibration graph. The percentage recoveries were found within acceptable range $(100 \pm 10)$ for all the elements, except for $\mathrm{K}(77.5 \%)$ and $\mathrm{Na}(75 \%)$. Indeed, low recoveries are expected for $\mathrm{Na}$ and $\mathrm{K}$, because these metals cannot be fully extracted from silicate lattice (Chen and Ma 2001) using aqua regia.

\section{Extraction and determination of vitamin $\mathrm{C}$ in fruit samples} Total ascorbic acid (vitamin C) content was determined by 2,4-dinitophenylhydrazine (DNPH) method (Kapur et al. 2012). A homogenized sample $(5.0000 \mathrm{~g})$ of the fruit was used for this analysis. To study the recovery of total ascorbic acid using the selected method $0.4 \mathrm{~mL}$ of of L-ascorbic acid $(1 \mathrm{mg} / \mathrm{mL})$ standard was added to $5.000 \mathrm{~g}$ of wet fruit sample to give $0.8 \mu \mathrm{g}$ ascorbic acid/ $\mathrm{mL}$ in the final stage of the analysis. The mixture was extracted following the selected analytical procedure. Absorbance of the spiked samples was monitored by a $\mathrm{UV} / \mathrm{Vis}$ spectrophotometer at a wavelength of $521 \mathrm{~nm}$. Triplicates of analysis were done. A percentage recovery of $92.4 \pm 0.2$ was found. This confirms that the method is valid for the determination of total ascorbic acid in the fruits.

\section{Measurement of physico-chemical characteristics of soils} The soil $\mathrm{pH}$, electrical conductivity, texture, organic matter, available phosphorus, and cation exchange capacity (CEC) were determined by the reported methods (Tan 1996; Sertse and Taye 2000).

\section{Statistical analysis}

The analysis of variance for the equality of means and correlation between the elements in the fruit, water and soil samples were done using the SPSS 20.0. 


\section{Results and discussion} Moisture content of fruits

Results from food analysis are usually expressed on a wet weight basis. Thus it is important that no loss of moisture occur until the sample is weighed. Subsequently the sample can be dried either conventionally or by freezedrying. Freeze drying is favored by many workers (Van Loon, 1985). Freeze drying ensures high flavor retention and minimal damage to product structure and nutritional value; permits fast and nearly complete dehydration (Francis 2000).

The moisture contents (Table 1) of the fruits were determined by measuring the mass loss of the fruits using freeze-drying unit until constant mass was obtained. As can be seen from Table 1, the moisture content is the lowest for banana and the highest for mandarin. The order of moisture content in the fruits is mandarin $>$ orange $>$ grape $>$ guava $>$ banana. These values are comparable with literature values (Sanchez-Castillo et al. 1998; Francis 2000; Li and Anderw 2002).

\section{Concentration of metals in fruits}

The metal contents of the fruits are summarized in Table 2.

The pattern of concentrations of metals in banana is decreased as follows: $\mathrm{K}>\mathrm{Mg}>\mathrm{Ca}>\mathrm{Na}>\mathrm{Fe}>\mathrm{Zn}>\mathrm{M}$ $\mathrm{n}>\mathrm{Cu}$. The concentrations of $\mathrm{Pb}$ and $\mathrm{Cd}$ were below the detection limit of the method. Table 2 indicates that banana can be good source of both major and trace elements that are essential for our body. Especially, banana is a good source of $\mathrm{Mg}(270 \mu \mathrm{g} / \mathrm{g}$ wet weight $)$ and $\mathrm{K}$ (3620 $\mu \mathrm{g} / \mathrm{g}$ wet weight) compared to other selected fruits. The obtained concentrations are within the ranges of literature values. For instance the trace element intervals for banana reported in different literatures from 1968 to 1998 for $\mathrm{Ca}, \mathrm{Mg}, \mathrm{Fe}, \mathrm{Cu}, \mathrm{Zn}, \mathrm{Mn}, \mathrm{Pb}$, and $\mathrm{Cd}(\mu \mathrm{g} / \mathrm{g}$ edible portion) are: $20.0-500,190-440,3.4-9.0,0.7-$ 4.0, 1.5-3.4, and 0.6-14.0, respectively (Hardisson et al. 2001). In another literature, the values that were reported for banana (Cavendish variety) grown in Australia were 3300, 50, 330, 3 and $2 \mu \mathrm{g} / \mathrm{g}$ edible portion for $\mathrm{K}, \mathrm{Ca}, \mathrm{Mg}$, $\mathrm{Fe}$, and $\mathrm{Zn}$, respectively (Cunningham et al. 2001). These literature values are similar to the results obtained in this study.

The trend in concentrations of metals in grape is $\mathrm{K}>$ $\mathrm{Ca}>\mathrm{Mg}>\mathrm{Na}>\mathrm{Fe}>\mathrm{Mn}>\mathrm{Cu}>\mathrm{Zn}$. The average metal concentrations of grape are $13.7(\mathrm{Na}), 1780(\mathrm{~K}), 250(\mathrm{Ca})$, $60(\mathrm{Mg}), 3.8(\mathrm{Fe}), 2.6(\mathrm{Cu}), 2.2(\mathrm{Zn})$ and $3.4(\mathrm{Mn}) \mu \mathrm{g} / \mathrm{g}$ edible portion (Table 2). The obtained results are comparable with literature value (Miller-Ihli 1996). Table 2 shows that copper content of grape is highest compared to other analyzed fruits.

The concentration pattern of the metals in guava is $\mathrm{K}$ $>\mathrm{Ca}>\mathrm{Mg}>\mathrm{Na}>\mathrm{Fe}>\mathrm{Mn}>\mathrm{Zn}>\mathrm{Cu}>\mathrm{Cd}$. The average

Table 1 The moisture content of fruits (mean \pm SD, $n=9$ )

\begin{tabular}{|c|c|c|c|c|}
\hline \multirow[t]{2}{*}{ Fruit } & \multicolumn{4}{|l|}{ Moisture (\%) } \\
\hline & Found in this study (Ethiopia) & Literature value & Country & Reference \\
\hline Banana & $74.9 \pm 0.2$ & 76.0 & Netherlands & Francis (2000) \\
\hline \multirow[t]{3}{*}{ Grape } & $82.5 \pm 0.2$ & 83.0 & Netherlands & Francis (2000) \\
\hline & & 85.3 & Bangladesh & Paul and Shaha (2004) \\
\hline & & 81.5 & Mexico & Sanchez-Castillo et al. (1998) \\
\hline Guava & $79.7 \pm 0.4$ & 81.0 & Netherlands & Francis (2000) \\
\hline Mandarin & $88.4 \pm 0.4$ & 88.0 & Netherlands & Francis (2000) \\
\hline \multirow[t]{3}{*}{ Orange } & $85.9 \pm 0.3$ & 87.0 & Netherlands & Francis (2000) \\
\hline & & 87.8 & Bangladesh & Paul and Shaha (2004) \\
\hline & & 85.5 & Mexico & Sanchez-Castillo et al. (1998) \\
\hline
\end{tabular}

Table 2 Metal levels in fruit samples (mean $\pm S D, n=6$ )

\begin{tabular}{|c|c|c|c|c|c|c|c|c|c|c|}
\hline \multirow[t]{2}{*}{ Fruit } & \multicolumn{10}{|c|}{ Concentration of metals ( $\mu \mathrm{g} / \mathrm{g}$ edible portion) } \\
\hline & $\mathrm{Na}$ & $\mathbf{K}$ & $\mathrm{Ca}$ & Mg & $\mathrm{Fe}$ & $\mathrm{Cu}$ & $\mathrm{Zn}$ & Mn & $\mathrm{Pb}$ & Cd \\
\hline Banana & $6.4 \pm 0.2$ & $3480 \pm 20$ & $75.0 \pm 1$ & $281 \pm 1$ & $4.6 \pm 0.1$ & $0.8 \pm 0.1$ & $2.3 \pm 0.1$ & $1.2 \pm 0.1$ & ND & ND \\
\hline Grape & $13.7 \pm 0.3$ & $1780 \pm 30$ & $250 \pm 1$ & $60.0 \pm 1$ & $3.8 \pm 0.2$ & $2.6 \pm 0.1$ & $2.2 \pm 0.1$ & $3.4 \pm 0.2$ & ND & ND \\
\hline Guava & $15.6 \pm 0.2$ & $2080 \pm 50$ & $481 \pm 3$ & $140 \pm 2$ & $5.6 \pm 0.1$ & $1.2 \pm 0.1$ & $1.4 \pm 0.1$ & $4.8 \pm 0.1$ & ND & $0.200 \pm 0.004$ \\
\hline Orange & $14.7 \pm 0.1$ & $1220 \pm 20$ & $554 \pm 1$ & $79.0 \pm 1$ & $2.6 \pm 0.1$ & $0.7 \pm 0.1$ & $1.6 \pm 0.1$ & $1.3 \pm 0.1$ & ND & $0.300 \pm 0.01$ \\
\hline Mandarin & $10.6 \pm 0.2$ & $1380 \pm 20$ & $286 \pm 11$ & $84.0 \pm 3$ & $2.5 \pm 0.1$ & $0.3 \pm 0.01$ & $1.2 \pm 0.1$ & $0.3 \pm 0.01$ & ND & $0.13 \pm 0.01$ \\
\hline
\end{tabular}

ND not detected 
concentrations of metals in guava are $15.6(\mathrm{Na}), 2080$ (K), $481(\mathrm{Ca}), 140(\mathrm{Mg}), 5.6(\mathrm{Fe}), 1.2(\mathrm{Cu}), 1.4(\mathrm{Zn}), 4.8$ $(\mathrm{Mn})$ and $0.2(\mathrm{Cd}) \mu \mathrm{g} / \mathrm{g}$ edible portion. EHNRI (1998) has reported $72(\mathrm{Na}), 2290(\mathrm{~K}), 170(\mathrm{Ca}), 6.4(\mathrm{Fe}), 8.4(\mathrm{Cu})$ and 2.4 $(\mathrm{Zn}) \mu \mathrm{g} / \mathrm{g}$ edible portion for guava from Sidamo, Ethiopia and $60(\mathrm{Na}), 2110(\mathrm{~K}), 320(\mathrm{Ca}), 30(\mathrm{Fe}), 3.7(\mathrm{Cu})$, and $1.4(\mathrm{Zn}) \mu \mathrm{g} / \mathrm{g}$ edible portion for guava from Konso, Ethiopia. These values are nearly similar to those found in the guava from Nura Era Farm except that amount of $\mathrm{Ca}$ is higher and amount of $\mathrm{Na}$ is lower compared to guava from Konso and Sidamo. In this study it was found that guava contains highest amount of $\mathrm{Mn}, \mathrm{Na}$ and $\mathrm{Fe}$ compared other selected fruits.

The elemental concentration pattern is $\mathrm{K}>\mathrm{Ca}>\mathrm{Mg}>$ $\mathrm{Na}>\mathrm{Fe}>\mathrm{Zn}>\mathrm{Mn}>\mathrm{Cu}>\mathrm{Cd}$. Ca content of mandarin is about half of the amount in orange. The average concentrations of metals in mandarin are $1380(\mathrm{~K}), 286(\mathrm{Ca}), 84$ $(\mathrm{Mg}), 10.6(\mathrm{Na}), 2.5(\mathrm{Fe}), 1.2(\mathrm{Zn}), 0.3(\mathrm{Cu}), 0.3(\mathrm{Mn})$ and $0.13(\mathrm{Cd}) \mu \mathrm{g} / \mathrm{g}$ edible portion (Table 2 ).

The concentration pattern of the metals in orange is $\mathrm{K}>\mathrm{Ca}>\mathrm{Mg}>\mathrm{Na}>\mathrm{Fe}>\mathrm{Zn}>\mathrm{Mn} \approx \mathrm{Cu}>\mathrm{Cd}$. There is a similarity in trends of the concentrations of metals in mandarin and orange. The average concentrations of metals in orange are $1220(\mathrm{~K}), 554(\mathrm{Ca}), 79(\mathrm{Mg}), 14.7$ $(\mathrm{Na}), 2.6(\mathrm{Fe}), 1.6(\mathrm{Zn}), 1.3(\mathrm{Mn}), 0.7(\mathrm{Cu})$ and $0.3(\mathrm{Cd})$ $\mu \mathrm{g} / \mathrm{g}$ edible portion (Table 2). EHNRI (1998) reported $500 \mu \mathrm{g} / \mathrm{g}$ for Ca and $8 \mu \mathrm{g} / \mathrm{g}$ for Fe in the edible portion of the fruit which is nearly similar to the values obtained in this study. The obtained results are also comparable with literature values other in other reports (Miller-Ihli 1996). Compared to other analyzed fruits, orange contains highest amount of $\mathrm{Ca}$ (Table 2).

Generally, for most metals the values are comparable with that reported in literature (Miller-Ihli 1996; EHNRI 1998; Hardisson et al. 2001). Pb was below the detection limit of the method in all the fruits analyzed. This may be because of the fact that $\mathrm{Pb}$ forms relatively insoluble minerals in soils (GVRD 1999). The pH of the soils (alkaline) of Awara Melka and Nura Era Farms (Table 3) also favors the insolubility, and therefore unavailability of lead. However, unlike $\mathrm{Pb}, \mathrm{Cd}$ was detected in guava, orange and mandarin, but its amount was below the detection limit of the method in banana and grape. It has been reported that $\mathrm{Cd}, \mathrm{Cu}$ and $\mathrm{Zn}$ were the main elements that plant could accumulate and pass up to the food chain. The detection of cadmium in the fruits is maybe because of the fact that cadmium ions are readily transferred from the soil to plants, which absorb the element and accumulate it to different degrees, depending on the species (Cabrera et al. 1992).

\section{Some characteristics of soil}

The impact of contaminated elemental uptake by plant roots is dependent upon many factors, including: the magnitude and chemical forms of trace element(s) present; soil $\mathrm{pH}$, moisture, aeration, temperature, organic matter and phosphate content; the presence or absence of other competing ions; the plant species; rooting depth, age; and seasonal growth effects (Fifield and Haines 1997). The physicochemical characteristics of the soils measured in this study are given in Table 3.

The $\mathrm{pH}$ values of the soil samples range from 7.87 to 8.23 which shows the soils of Awara Melka and Nura Era Farms are slightly alkaline (Table 3 ). Therefore, the availability of the trace elements is low in soils of Awara Melka and Nura Era Farms if only pH is considered. But availability of elements depends on other factors, therefore it is difficult to generalize that the availability of the elements in the soil are high. However one can say that the $\mathrm{pH}$ of the soil may contribute for the decrease in availability of the elements. Comparatively, the $\mathrm{pH}$ of orange and mandarin land is low compared to other lands (Table 3).

Table 3 shows that the organic contents of soil samples are low (1.52-2.84\%). These values show that the soils of Awara Melka and Nura Era Farms are mineral soil (University of Florida 2005). Information of organic content of soil does not provide much quantitative information to the farmer that is helpful in managing soils for crop

Table 3 Physicochemical characteristics of the soils collected from the Awara Melka and Nura Era farms

\begin{tabular}{|c|c|c|c|c|c|c|c|}
\hline Farm & Lands from which soil sample collected & $\mathrm{pH}$ & $\mathrm{EC}\left(\mu \mathrm{Scm}^{-1}\right)$ & OM (\%) & Clay and texture (\%) & $\begin{array}{l}\text { Available } \\
\mathrm{P}(\mathrm{mg} / \mathrm{kg})\end{array}$ & CEC (meq/kg) \\
\hline Awara Melka & Banana land & 8.11 & $185 \pm 2$ & 1.55 & $\begin{array}{l}40.3 \\
\text { (Clay loam) }\end{array}$ & 6.08 & 452 \\
\hline \multirow[t]{3}{*}{ Nura Era } & Orange, mandarin land & 7.87 & $319 \pm 3$ & 2.68 & $\begin{array}{l}45.2 \\
\text { (Clay) }\end{array}$ & 3.68 & 459 \\
\hline & Grape land & 8.23 & $174 \pm 2$ & 1.52 & $\begin{array}{l}37.8 \\
\text { (Clay loam) }\end{array}$ & 4.48 & 367 \\
\hline & Guava land & 8.00 & $184 \pm 4$ & 2.84 & $\begin{array}{l}45.4 \\
\text { (Clay) }\end{array}$ & 4.00 & 472 \\
\hline
\end{tabular}


production. Instead, the information is generally evaluated on a relative or comparative basis. For instance soils with a higher organic matter will have a higher cation exchange capacity and higher water holding capacity than soil with a lower organic matter (Allan Bande et al. 2002).

It was found that the electrical conductivity of soil from Awara Melka and Nura Era Farms ranges from 174 to $319 \mu \mathrm{Scm}^{-1}$, which shows the EC of the soils are low. The results, therefore, show that amount of ions in the soil are less. The EC of banana, grape, and guava lands are $185,174,184 \mu \mathrm{Scm}^{-1}$ while that of orange and mandarin lands is $319 \mu \mathrm{Scm}^{-1}$, which indicates there is much dissolved metals in the orange and mandarin land.

The CEC of the soil samples ranged from 367 to $472 \mathrm{meq} / \mathrm{kg}$ dry soil (Table 3). The CEC of grape land is lowest compared to other lands. CEC of soil from guava land is high (472 meq/kg dry soil) compared to soil samples from other lands. This may be the cause for higher accumulation of $\mathrm{Na}, \mathrm{Fe}$ and $\mathrm{Mn}$ in guava (Table 2).

High phosphorus concentrations in the soil decrease $\mathrm{Zn}$ availability, as do elevated soil concentrations of Fe, $\mathrm{Cu}$ and $\mathrm{Ca}$ (Cabrera et al. 1992). Phosphorus is strongly bound to particular soil minerals including aluminum and iron oxides. Table 3 shows that the available phosphorus in Awara Melka soil is higher compared to that of Nura Era soil.

Generally, the soils collected from Awara Melka and Nura Era Farms are similar in most of the soil characteristics (Table 3).

\section{Concentrations of metals in the soils}

Amount of metals in the soils collected from each lands in which fruits were planted are given in Table 4. The concentrations of the selected metals vary from farms to farm and lands to land in which fruits are grown. For this study the soil sample were categorized according to lands/blocks in which the fruits are grown. For instance the soil that was taken from blocks in which banana is grown (named in this case banana land) was analyzed separately. The results are given separately for each land of fruit. Soils from orange and mandarin land were pooled together because they are adjacent to each other and furthermore, application of fertilizers, insecticides, pesticides and irrigation programs are almost the same (Seifu 2003).

As can be seen from Table 4, sodium is higher in Awara Melka (banana land) soil compared to soils from Nura Era Farms (other lands of fruits). On the other hand, the average concentrations of $\mathrm{K}$ in soils from banana, orange and mandarin, grape, and guava lands are 5020, 7500, 9070 , and $6680 \mathrm{mg} / \mathrm{kg}$ dry soil, respectively. These values are nearly similar to each other. However, average concentration of $\mathrm{Ca}$ is different from land to land; highest in orange and mandarin land $(16,500 \mathrm{mg} / \mathrm{kg}$ dry weight $)$ and lowest in grape land $(7900 \mathrm{mg} / \mathrm{kg}$ dry weight). The average concentrations of $\mathrm{Mg}$ in the soils are 8400, 7700, 6400 , and $4600 \mathrm{mg} / \mathrm{kg}$ dry weight in banana, orange and mandarin, grape and guava lands, respectively.

Generally, the above metals are very abundant in nature in soils compared to trace elements. Therefore, their variation could be also large from lands to lands. The use of fertilizers could be also a source for these metals.

The average concentration ( $\mathrm{mg} / \mathrm{kg}$ dry soil) of Fe in the soil samples from banana land (Awara Melka), orange and mandarin, grape and guava land are 61,600, 42,300, 38,800 and 26,800, respectively (Table 4). Table 4 shows that there is highest concentration of Fe in Awara Melka Farm (banana land) compared to Nura Era Farm. Even though the values are in the range that has been reported for surface soil, it is above the maximum allowable level $(1500 \mathrm{mg} / \mathrm{kg})$ (FAO 1998). The average concentrations of $\mathrm{Mn}$ in the soil samples are also above the allowable value $(2000 \mathrm{mg} / \mathrm{kg}$ ) (Itana 2002). The average concentrations of Mn range from 2440 to $2950 \mathrm{mg} / \mathrm{kg}$ dry weight (Table 4). These values indicate that there is much amount of $\mathrm{Mn}$ in soils of Awara Melka and Nural Era Farms. The average concentration of copper in the sampled soils ranged from 17.3 (orange and mandarin land) to 32.7 (banana land) $\mathrm{mg} /$ $\mathrm{kg}$ dry soil. The values are in range reported for surface soil $(5-80 \mathrm{mg} / \mathrm{kg})$. The concentrations of $\mathrm{Cu}$ in the sampled soils are also below maximum allowable level $(100 \mathrm{mg} / \mathrm{kg})$

Table 4 Average metal concentration in soils from Awara Melka and Nura Era Farms, (mean $\pm S D, n=6)$

\begin{tabular}{|c|c|c|c|c|c|c|c|c|c|c|c|}
\hline \multirow[t]{2}{*}{ Farm } & \multirow[t]{2}{*}{ Fruit land } & \multicolumn{10}{|c|}{ Concentration of metals in soils (mg/kg dry soil) } \\
\hline & & $\mathrm{K}$ & $\mathrm{Ca}$ & $\mathrm{Mg}$ & $\mathrm{Fe}$ & $\mathrm{Mn}$ & $\mathrm{Cu}$ & $\mathrm{Zn}$ & $\mathrm{Pb}$ & $\mathrm{Cd}$ & $\mathrm{Na}$ \\
\hline $\begin{array}{l}\text { Awara } \\
\text { Melka }\end{array}$ & $\begin{array}{c}\text { Banana } \\
\text { land }\end{array}$ & $5020 \pm 50$ & $13,200 \pm 200$ & $8400 \pm 100$ & $61,600 \pm 200$ & $2440 \pm 60$ & $32.7 \pm 0.5$ & $111 \pm 1.4$ & $15.3 \pm 0.6$ & $3.54 \pm 0.16$ & $211 \pm 2.8$ \\
\hline \multirow[t]{3}{*}{ Nura Era } & $\begin{array}{l}\text { Orange, } \\
\text { manda- } \\
\text { rin land }\end{array}$ & $7500 \pm 170$ & $16,500 \pm 200$ & $7700 \pm 300$ & $42,800 \pm 1500$ & $2950 \pm 90$ & $17.3 \pm 0.9$ & $130 \pm 1.3$ & $31.3 \pm 1.7$ & $6.23 \pm 0.40$ & $125 \pm 5.1$ \\
\hline & Grape land & $9070 \pm 80$ & $7900 \pm 100$ & $6400 \pm 100$ & $38,800 \pm 100$ & $2940 \pm 110$ & $25.6 \pm 0.9$ & $114 \pm 2.3$ & $32.2 \pm 0.9$ & $2.54 \pm 0.20$ & $51.8 \pm 3.3$ \\
\hline & Guava land & $6680 \pm 110$ & $10,400 \pm 300$ & $4600 \pm 200$ & $26,800 \pm 200$ & $2300 \pm 80$ & $23.1 \pm 1.1$ & $128 \pm 1.7$ & $22.9 \pm 0.5$ & $3.69 \pm 0.13$ & $70.2 \pm 3.3$ \\
\hline
\end{tabular}


(Itana 2002). The average concentration of $\mathrm{Zn}$ in soil samples is almost equal in orange and mandarin land $(130 \mathrm{mg} /$ $\mathrm{kg}$ dry soil) and guava land (128 mg/kg dry soil). Similarly, average concentrations of $\mathrm{Zn}$ in banana and grape land are 111 and $114 \mathrm{mg} / \mathrm{kg}$ dry soil, respectively. In all cases the amount of $\mathrm{Zn}$ in the soil samples are below the maximum allowable level (300 mg/kg) (Itana 2002).

The average concentrations of $\mathrm{Pb}$ in soil samples are found higher in Nura Era Farm compared to that of Awara Melka Farm. The values are in the ranges that are reported for surface soil (Fifield and Haines 1997; Tokaliouglu et al. 2003). All the values are below the maximum allowable level $(100 \mathrm{mg} / \mathrm{kg})$ (Tokaliouglu et al. 2003). The average concentration of $\mathrm{Cd}$ in soil samples are above is the maximum allowable level (3 mg/kg) (Itana 2002) except for soils from grape land. The most probable source of $\mathrm{Cd}$ is phosphates fertilizers and may be pesticides.

Generally the concentrations of $\mathrm{Cu}, \mathrm{Zn}$, and $\mathrm{Pb}$ in soil samples are in the ranges that have been reported for surface soils. To some extent the concentration of $\mathrm{Cd}$, and to most extent the concentration of $\mathrm{Mn}$ and $\mathrm{Fe}$ are above the ranges reported for surface soils (Fifield and Haines 1997; Tokaliouglu et al. 2003). The concentration of $\mathrm{Cu}$ in soil from Awara Melka is higher compared to that of Nura Era Farm soil samples. The reverse is true for $\mathrm{Zn}$. Concentrations of $\mathrm{Pb}$, is higher at Nura Era Farm compared to that of Awara Melka. Cd is higher in lands in which orange and mandarin are planted. Relatively $\mathrm{Zn}$ is higher in soil from Nura Era Farm (Table 4).

\section{Concentrations of metals in the water samples}

The concentrations of metals in the irrigation water collected from the farm channels are generally higher than waters collected from the rivers from which the irrigation water is taken (Table 5). This can be from the soil, fertilizers and pesticides added to the soil.

Awash River contains higher amounts of $\mathrm{Fe}, \mathrm{Cu}$, $\mathrm{Zn}, \mathrm{Mn}$, and $\mathrm{Cd}$ than Bulga River. Similar pattern was obtained for these metals in irrigation water from channels. From agricultural point of view, the maximum concentration limits of metals in irrigation waters are $(\mu \mathrm{g} / \mathrm{L})$ : $17(\mathrm{Cu}), 2000(\mathrm{Zn}), 200(\mathrm{Mn}), 65(\mathrm{~Pb})$ and $10(\mathrm{Cd})$ (Itana 2002). The concentrations of $\mathrm{Zn}, \mathrm{Mn}, \mathrm{Pb}$, and $\mathrm{Cd}$ in the waters from the rivers are below the maximum limit. But $\mathrm{Cu}$, in the river water is slightly higher than the maximum recommended limit.

\section{Total ascorbic acid in the fruits obtained from the selected farms}

The concentrations of ascorbic acid in the fruits have been determined from the external calibration curve $\left(R^{2}=0.9994\right)$ obtained with standard solution. From Table 6, the ascorbic acid content ranges from 51 (grape) to $1170 \mu \mathrm{g}$ ascorbic acid/g edible portion (guava). This indicates that guava is rich in ascorbic acid contents. This has been also shown by many literature reports (Paul and Shaha 2004). Orange is also shown to be a good source of ascorbic acid compared to the other fruits analyzed.

It is pointed out that the tropical guava, Psidium guajava, is regarded as an excellent source of vitamin $\mathrm{C}$, but there is greater variation in vitamin $\mathrm{C}$ level amongst the various cultivated varieties. For example, the variety "Donaldan" has $3720 \mu \mathrm{g} / \mathrm{g}$ flesh, but variety, 'Supreme' has only $440 \mu \mathrm{g} / \mathrm{g}$ edible portion (UHIS 2001). Some South African pink guava cultivars grown for the canning industry are said to have an astonishing $4000 \mu \mathrm{g} / \mathrm{g}$ edible portion (UHIS 2001). The origin of this variation can be due to difference in the variety of the fruits, climate, maturity at which the fruits collected, handling during collection, storage and methods used for the analysis.

\section{Comparison of metal concentration in soil, water and fruit samples}

The concentration of metal in soil $(\mathrm{mg} / \mathrm{kg})$, water $(\mathrm{mg} / \mathrm{L})$ and fruit $(\mathrm{mg} / \mathrm{kg})$ samples are given in Table 7 . The

Table 5 Average metal concentration and their ranges in water samples collected from Rivers and Channels used to irrigate Awara Melka and Nura Era Farms (mean $\pm S D, n=4)$

\begin{tabular}{|c|c|c|c|c|c|c|c|c|c|c|c|}
\hline \multirow[t]{2}{*}{ Farm } & \multirow{2}{*}{$\begin{array}{l}\text { River/ } \\
\text { irrigation } \\
\text { channels }\end{array}$} & \multicolumn{10}{|c|}{ Concentration of metals (mg/L) } \\
\hline & & $\mathrm{Na}$ & $\mathrm{K}$ & $\mathrm{Ca}$ & $\mathrm{Mg}$ & $\mathrm{Fe}$ & $\mathrm{Cu}$ & $\mathrm{Zn}$ & $M n$ & $\mathrm{~Pb}$ & $\mathrm{Cd}$ \\
\hline \multirow[t]{4}{*}{ Awara Melka } & Bulga river & $20.8 \pm 0.2$ & $13.3 \pm 0.4$ & $28.0 \pm 0.1$ & $11.8 \pm 0.1$ & $0.038 \pm 0.001$ & $0.024 \pm 0.001$ & $0.026 \pm 0.001$ & $0.068 \pm 0.001$ & ND & $0.0043 \pm 0.001$ \\
\hline & Channels & & & & & & & & & & \\
\hline & Mean & $28.3 \pm 0.3$ & $15.1 \pm 0.4$ & $38.4 \pm 0.1$ & $12.5 \pm 0.6$ & $0.036 \pm 0.004$ & $0.046 \pm 0.005$ & $0.022 \pm 0.002$ & $0.080 \pm 0.004$ & ND & $0.0075 \pm 0.0003$ \\
\hline & Range & $26.9-29.0$ & $11.1-24.3$ & $22.2-34.4$ & $8.3-17.4$ & $0.032-0.037$ & $0.043-0.048$ & $<0.001-0.037$ & $0.062-0.096$ & ND & $0.0073-0.0078$ \\
\hline \multirow[t]{4}{*}{ Nura Era } & Awash river & $14.9 \pm 0.2$ & $13.2 \pm 0.6$ & $26.9 \pm 0.1$ & $6.7 \pm 0.1$ & $0.142 \pm 0.012$ & $0.037 \pm 0.002$ & $0.092 \pm 0.002$ & $0.106 \pm 0.002$ & ND & ND \\
\hline & Channels & & & & & & & & & & \\
\hline & Mean & $16.3 \pm 0.5$ & $15.2 \pm 0.6$ & $28.6 \pm 0.4$ & $6.8 \pm 0.2$ & $0.352 \pm 0.011$ & $0.044 \pm 0.005$ & $0.061 \pm 0.005$ & $0.090 \pm 0.006$ & ND & $0.0070 \pm 0.004$ \\
\hline & Range & $12.8-18.8$ & $12.7-19.7$ & $22.0-33.1$ & $5.8-8.0$ & $0.124-0.709$ & $0.011-0.066$ & $0.012-0.184$ & $0.053-0.125$ & ND & $<0.0001-0.0091$ \\
\hline
\end{tabular}

ND not detected 
Table 6 Average concentrations of total ascorbic acid in the fruits (mean $\pm S D, n=6$ )

\begin{tabular}{llccll}
\hline No. & Fruit & \multicolumn{2}{l}{ Concentration $(\boldsymbol{\mu g}$ AA/g edible portion) } & & \\
\cline { 3 - 6 } & & Found in this study (Ethiopia) & Literature values & Country & Reference \\
\hline 1 & Banana & $90 \pm 3$ & 127 & USA & Wall (2006) \\
2 & Grape & $51 \pm 1$ & 230 & Bangladesh & Paul and Shaha (2004) \\
3 & Guava & $1170 \pm 60$ & 4000 & South Africa & UHIS (2001) \\
4 & Mandarin & $193 \pm 7$ & 340 & Australia & Mitchell et al. (1992) \\
5 & Orange & $282 \pm 11$ & 620 & Bangladesh & Paul and Shaha (2004) \\
\hline
\end{tabular}

Table 7 Comparison of metal concentrations in the soil, water and fruit samples

\begin{tabular}{llllll}
\hline Metal & $\begin{array}{l}\text { Concentration range } \\
\text { in soil }(\mathbf{m g} / \mathbf{k g})\end{array}$ & $\begin{array}{l}\text { Concentration range } \\
\text { in water }(\mathbf{m g} / \mathbf{L})\end{array}$ & $\begin{array}{l}\text { Concentration range } \\
\text { in fruit } \mathbf{( m g / k g ~ e d i b l e} \\
\text { part) }\end{array}$ & $\begin{array}{l}\text { Accumulation factor } \\
\text { from soil to water }\end{array}$ & $\begin{array}{l}\text { Accumulation factor } \\
\text { from water to fruit }\end{array}$ \\
\hline $\mathrm{Na}$ & $51.8-211$ & $12.8-29.0$ & $6.40-10.6$ & 0.137 & 0.366 \\
$\mathrm{~K}$ & $5020-9070$ & $11.1-24.3$ & $1220-3480$ & 0.00268 & 143 \\
$\mathrm{Ca}$ & $7900-16,500$ & $22.0-38.4$ & $75.0-554$ & 0.00233 & 14.4 \\
$\mathrm{Mg}$ & $5600-8400$ & $5.80-17.4$ & $60.0-281$ & 0.00207 & 76.1 \\
$\mathrm{Fe}$ & $26,800-61,200$ & $0.032-0.709$ & $2.5-5.6$ & 0.0000438 & 39.4 \\
$\mathrm{Cu}$ & $17.3-32.7$ & $0.011-0.066$ & $0.3-2.6$ & 0.00202 & 12.5 \\
$\mathrm{Zn}$ & $111-128$ & $<0.001-0.184$ & $1.2-2.3$ & 0.00144 & 38.4 \\
$\mathrm{Mn}$ & $2300-2950$ & $0.053-0.125$ & $0.3-4.8$ & 0.0000424 & 33.0 \\
$\mathrm{Cd}$ & $2.5-6.2$ & $<0.0001-0.0091$ & $<0.1-0.3$ & 0.00147 & -
\end{tabular}

accumulation factors of metals from soil to water and from water to fruit samples are calculated by taking the highest concentration (the upper end of the range) of the metals in the soil, water and fruit samples (Table 7). The data in Table 7 clearly show that all the metals are present in the soils at much higher concentrations than in the water samples. This indicates that the metals are mostly present in the soils as insoluble species and hence their accumulation/mobilization factors (from soil to water) are much low $(\leq 0.002)$ except for Na. In contrast to this, the concentrations of metals in the fruits are much higher than in the water samples. The accumulation factors of metals (from water to fruit) are much higher (8-143) except for $\mathrm{Na}$ whose accumulation factor is less than one (0.37). Among the other nine metals, accumulation factors vary from metal to metal, Fe has the lowest accumulation factor (7.9) while $\mathrm{K}$ has the highest accumulation factor (143). The differences in the accumulation factors may be due to differences in the ability of individual metals to form complexes with different formation/stability constants.

\section{Analysis of variance}

Analysis of variance (ANOVA) is widely used statistical methods to compare the mean of more than two groups of sample. ANOVA uses the F statistic to compare whether the differences between sample means are significant or not (Miller and Miller 2005).

In this study, five fruit samples were collected from two different areas and the metal levels of each sample was analysed by FAAS. During the processes of sample preparation and analysis a number of random errors may be introduced in each aliquot and in each replicate measurement. The variation in sample mean of the analyte was tested by using ANOVA, whether the source for variation was experimental procedure or heterogeneity among the samples.

The ANOVA results (Table 8) showed that there exist statistically significant differences at $95 \%$ confidence level in mean concentrations of all the metals. The source for this significant difference between sample means may be the difference in mineral contents of soil, $\mathrm{pH}$ of soil, water, atmosphere; variation in application of agrochemicals like fertilizers, pesticides, herbicides or other variations in cultivation procedures.

Pearson correlation of metals between soil and fruit and between water and fruit samples

In this study, to correlate the effect of one metal concentration on the concentration of the other metal in the 
Table 8 Analysis of variance (ANOVA) between and within fruit samples at $95 \%$ confidence level

\begin{tabular}{|c|c|c|c|c|c|}
\hline Metal & Comparison & df & $\mathrm{F}_{\text {calculated }}$ & $F_{\text {critical }}$ & Remark \\
\hline \multirow[t]{2}{*}{$\mathrm{Na}$} & Between samples & 4 & 319.66 & 3.48 & Significant difference between sample means \\
\hline & Within samples & 10 & & & \\
\hline \multirow[t]{2}{*}{ K } & Between samples & 4 & 879.70 & 3.48 & Significant difference between sample means \\
\hline & Within samples & 10 & & & \\
\hline \multirow[t]{2}{*}{$\mathrm{Ca}$} & Between samples & 4 & 1375.34 & 3.48 & Significant difference between sample means \\
\hline & Within samples & 10 & & & \\
\hline \multirow[t]{2}{*}{$\mathrm{Mg}$} & Between samples & 4 & 2539.91 & 3.48 & Significant difference between sample means \\
\hline & Within samples & 10 & & & \\
\hline \multirow[t]{2}{*}{$\mathrm{Fe}$} & Between samples & 4 & 109.50 & 3.48 & Significant difference between sample means \\
\hline & Within samples & 10 & & & \\
\hline \multirow[t]{2}{*}{$\mathrm{Cu}$} & Between samples & 4 & 98.13 & 3.48 & Significant difference between sample means \\
\hline & Within samples & 10 & & & \\
\hline \multirow[t]{2}{*}{$\mathrm{Zn}$} & Between samples & 4 & 23.80 & 3.48 & Significant difference between sample means \\
\hline & Within samples & 10 & & & \\
\hline \multirow[t]{2}{*}{$\mathrm{Mn}$} & Between samples & 4 & 242.87 & 3.48 & Significant difference between sample means \\
\hline & Within samples & 10 & & & \\
\hline
\end{tabular}

$d f$ degree of freedom of between sample and within sample

same sample and to correlate the effect of the same metal concentration of soil to that of fruit and water to that of fruit, the Pearson correlation matrices using correlation coefficient $(r)$ for the samples were used. The results are given in Tables 9 and 10.

There was high positive correlation for $\mathrm{Na}$ with (Ca and $\mathrm{Mn}), \mathrm{K}$ with $(\mathrm{Mg}, \mathrm{Fe}, \mathrm{Zn})$, Fe with $\mathrm{Mn}$, and $\mathrm{Cu}$ with $\mathrm{Mn}$ and moderate correlation for $\mathrm{Na}$ with $\mathrm{Cu}, \mathrm{Ca}$ with $\mathrm{Mn}, \mathrm{Mg}$ with (Fe and $\mathrm{Zn})$, Fe with $(\mathrm{Cu}$ and $\mathrm{Zn})$ and $\mathrm{Cu}$ with $\mathrm{Zn}$; which may arise from common anthropogenic or natural sources as well as from similarity in chemical properties. The high negative correlation for $\mathrm{Na}$ with (K and $\mathrm{Mg}$ ), $\mathrm{K}$ with $\mathrm{Ca}, \mathrm{Ca}$ with ( $\mathrm{Mg}$ and $\mathrm{Zn}$ ) indicate the large absorption of Na may affect the absorption of $\mathrm{K}$ and $\mathrm{Mg}$, $\mathrm{K}$ may affect $\mathrm{Ca}$, and $\mathrm{Ca}$ may affect $\mathrm{Mg}$ and $\mathrm{Zn}$ in the fruits. The other metals have weak negative or positive correlation indicating that the presence or absence of one metal affects the other to a lesser extent.

Pearson correlation coefficients for metals in soil to fruit and water to fruit samples (Table 10) indicate that $\mathrm{Na}, \mathrm{K}$ and $\mathrm{Ca}$ have negative correlations which indicate that higher concentration of these three metals in the soil and water result in lower concentration of these metals in the fruits. $\mathrm{Mg}$ and $\mathrm{Mn}$ positively correlate to each other indicating a proportional translocation of these metals from soils and water into fruits (Al-Lahham et al., 2007). Fe correlated positively with soil and fruit but negatively with water and fruit while $\mathrm{Cu}$ has negative correlation between soil and fruit and positive correlation between water and fruit. $\mathrm{Zn}$ has negligible positive correlation between soil and fruit and strong negative correlations between water and fruit. These findings verify the

Table 9 Correlation matrices for metals in fruit samples $(n=5)$

\begin{tabular}{|c|c|c|c|c|c|c|c|c|}
\hline & $\mathrm{Na}$ & $\mathrm{K}$ & $\mathrm{Ca}$ & $\mathrm{Mg}$ & $\mathrm{Fe}$ & $\mathrm{Cu}$ & $\mathrm{Zn}$ & $\mathrm{Mn}$ \\
\hline $\mathrm{Na}$ & 1.000 & & & & & & & \\
\hline K & -0.711 & 1.000 & & & & & & \\
\hline $\mathrm{Ca}$ & 0.872 & -0.719 & 1.000 & & & & & \\
\hline Mg & -0.740 & 0.949 & -0.592 & 1.000 & & & & \\
\hline $\mathrm{Fe}$ & 0.028 & 0.645 & -0.142 & 0.545 & 1.000 & & & \\
\hline $\mathrm{Cu}$ & 0.346 & 0.014 & -0.122 & -0.288 & 0.31 & 1.000 & & \\
\hline $\mathrm{Zn}$ & -0.437 & 0.652 & -0.639 & 0.46 & 0.273 & 0.564 & 1.000 & \\
\hline $\mathrm{Mn}$ & 0.622 & 0.052 & 0.307 & -0.114 & 0.761 & 0.648 & 0.072 & 1.000 \\
\hline
\end{tabular}


Table 10 Pearson correlation coefficient for metals in soil to fruit and water to fruit samples

\begin{tabular}{lllllllrr}
\hline Metal & $\mathbf{N a}$ & $\mathbf{K}$ & $\mathbf{C a}$ & $\mathbf{M g}$ & $\mathrm{Fe}$ & $\mathrm{Cu}$ & $\mathbf{Z n}$ & $\mathbf{M n}$ \\
\hline$r_{\text {soil-fruit }}$ & -0.963 & -0.547 & -0.676 & 0.574 & 0.499 & -0.759 & 0.0058 \\
$r_{\text {water-to-fruit }}$ & -0.248 & -0.754 & -0.275 & 0.265 & -0.593 & 0.532 & -0.968 & 0.923 \\
\hline
\end{tabular}

$r_{\text {soil-fruit }}$ and $r_{\text {water-fruit }}$ are the Pearson correlation coefficients between metal level in soil and fruit and between metal level in water and fruit, respectively

dependence of metal concentrations in the fruit plant on their concentrations in soil and water media.

\section{Conclusions}

In this study, fruits including banana, grape, guava, mandarin, and orange were analyzed for their content of $\mathrm{Na}$, $\mathrm{K}, \mathrm{Ca}, \mathrm{Mg}, \mathrm{Fe}, \mathrm{Cu}, \mathrm{Zn}, \mathrm{Mn}, \mathrm{Pb}$, and $\mathrm{Cd}$. It was found that banana (Cavendish variety) contains the highest amounts of $\mathrm{Mg}$ and $\mathrm{K}$ compared to other fruits. Therefore, banana can be a good source of $\mathrm{Mg}$ and $\mathrm{K}$. The analysis showed that guava is rich in total ascorbic acid content. Mandarin and orange also contain appreciable amount of total ascorbic acid. The results generally indicate that the consumption of these fruits can satisfy daily intake of vitamin $\mathrm{C}$ of the society to some extent. The detection of cadmium in some fruits indicates its translocation from the soils that already contained concentrations above the maximum allowable limits. Water could be also the source of cadmium that contributes to the accumulation of this metal in soil and fruits.

\section{Authors' contributions}

BSC and TW contributed to design of the study. SGY contributed to the sampling and analysis. CA contributed to the analysis. SGY, BSC and TW contributed to the interpretation of data and drafting the manuscript. BSC and TW contributed to critical revision of the paper. All authors have read and approved the final manuscript.

\section{Author details}

${ }^{1}$ Department of Chemistry, College of Natural Sciences, Addis Ababa University, P. O. Box 1176, Addis Ababa, Ethiopia. ${ }^{2}$ Present Address: Department of Chemistry, Johannesburg University, P. O. Box 524, Auckland Park, Johannesburg 2006, South Africa. ${ }^{3}$ Nutritional and Food Science Department, Ethiopian Health and Nutritional Research Institute, P. O. Box 1242, Addis Ababa, Ethiopia.

\section{Acknowledgements}

Financial assistance by the Swedish International Development Agency (SIDA) through the Ethiopian Science and Technology Commission and the Office of Research and Graduate Programs and Department of Chemistry of Addis Ababa University, Ethiopia is gratefully acknowledged. Shambel G Yami acknowledges financial support made by Dilla College, Ethiopia.

\section{Competing interests}

The authors declare that they have no competing interests.

\section{Funding}

This work was funded by Research and Graduate Programs of Addis Ababa University, Ethiopia. Research and Graduate Programs of Addis Ababa University, Ethiopia had no role in the design, data collection, analysis or publication of the manuscript.
Received: 28 March 2016 Accepted: 20 May 2016

Published online: 16 June 2016

\section{References}

Akhtar S, Naz S, Sultan MT, Mahmood S, Nasir M, Ahmad A (2010) Physicochemical attributes and heavy metal content of mangoes (Mangifera indica L.) cultivated in different regions of Pakistan. Pak J Bot 42:2691-2702

Al-Lahham O, El Assi NM, Fayyad M (2007) Translocation of heavy metals to tomato (Solanum lycopersicom L.) fruit irritated with treated water. Sci Hort 113:250-254

Allan Bande V, James B, Meisinger JJ (2002) Basic principles of soil fertility II: soil properties. http://www.agnr.umd.edu/MCE/Publications/PDFs/FS640.pdf Accessed June 2015

Ang LH, Ng LT (2000) Trace element concentration in mango (Mangifera indica L.), seedless guava (Psidium guajava L.) and papaya (Carica papaya L.) grown on agricultural and ex-mining lands of Bidor, Perak. Pertanika J Trop Agric Sci 23:15-22

Atlabachew M, Chandravanshi BS, Redi M (2011) Profile of major, minor and toxic metals in soil and khat (Catha edulis Forsk) cultivars in Ethiopia. Trends Appl Sci Res 6:640-655

Basha AM, Yasovardhan N, Satyanarayana SV, Reddy GVS, Kumar AV (2014) Trace metals in vegetables and fruits cultivated around the surroundings of Tummalapalle uranium mining site, Andhra Pradesh, India. Toxicol Rep 1:505-512

Cabrera C, Lorenzo ML, Gallego C, Lopez MC, Lillo E (1992) Cadmium levels in food and feed crops, determined by electrothermal atomic absorption spectrometry. J Agric Food Chem 40:1631-1633

Chen M, Ma QL (2001) Comparison of three aqua regia digestion methods for twenty Florida soils. Soil Sci Soc Am J 65:491-499

Clemson University (2000) Agricultural Service Laboratory, Plant tissue and feed and forage analysis procedures, May 3, 2000. http://www.clemson. edu/agsrvlb/procedures2/photo.htm Accessed June 2015

Cunningham JH, Milligan G, Trevisan L (2001) Minerals in Australian fruits and vegetables - a comparison of levels between the 1980s and 2000. Food Standards Australia New Zealand, Canberra

D'Mello JPF (2003) Food safety: contamination and toxins. UK, CABI Publishing, Willingford

EHNRI (Ethiopian Health and Nutritional Research Institute) (1998). Food composition table for use in Ethiopia IV. Addis Ababa, Ethiopian Health and Nutritional Research Institute (EHNRI) and the FAO (Food and Agriculture Organization) of the United Nations

Elbagermi MA, Edwards HGM, Alajtal Al (2012) Monitoring of heavy metal content in fruits and vegetables. Int Sch Res Net Anal Chem. doi:10.5402/2012/827645

FAO (Food and Agriculture Organization) (1998) Animal feeding and food safety. Food and Nutrition Paper 69. Rome, Italy, Food and Agriculture Organization of the United Nations

Fifield FW, Haines PJ (eds) (1997) Environmental analytical chemistry. Blackie Academic and Professional, London

Francis FJ (ed) (2000) Wiley encyclopedia of food science and technology, vol 2, 2nd edn. Wiley, New York

GVRD (The Greater Vancouver Regional District) (1999) The biosolids report a technical bulletin prepared by the GVRD to provide B.C. medical and 
environmental health officers with information about biosolids; Report no. 2

Hardisson A, Rubio C, Baez A, Martin M, Alvarez R, Diaz E (2001) Mineral composition of the banana (Musa acuminata) from the island of Tenerife. Food Chem 73:153-161

Igwegbe AO, Agukwe CH, Negbenebor CA (2013) A survey of heavy metal (lead, cadmium and copper) contents of selected fruit and vegetable crops from Borno State of Nigeria. Res Inv Int J Eng Sci 2:1-5

Itana $\mathrm{F}$ (2002) Metals in leafy vegetables grown in Addis Ababa and toxicological implications. Ethiop J Health Dev 16:295-302

Kalagbor IA, Naifa PB, Umeh JN (2014) Analysis of heavy metals in four fruits from Sii and Zaakpon communities in Khana, Rivers State. Int J Emerg Technol Adv Eng 4:827-831

Kapur A, Hasković A, Čopra-Janićijević A, Klepo L, Topčagić A, Tahirović I, Sofić E (2012) Spectrophotometric analysis of total ascorbic acid content in various fruits and vegetables. Bull Chem Technol Bosnia Herzegovina 38:39-42

Kitata RB, Chandravanshi BS (2012) Concentration levels of major and trace metals in onion (Allium cepa L.) and irrigation water around Meki Town and Lake Ziway, Ethiopia. Bull Chem Soc Ethiop 26:27-42

Li BW, Anderw KW (2002) Individual sugars, soluble, and insoluble dietary fiber contents of 70 high consumption foods. J Food Compos Anal 15:715-723

Maggini S, Wenzlaff S, Horing D (2010) Essential role of vitamin C and zinc in child immunity and health. J Int Med Res 38:386-414

Maroto A, Boque R, Rius FX (2001) Measurement uncertainty in analytical methods in which trueness is assessed from recovery assays. Anal Chim Acta 440:171-184

Mausi G, Simiyu G, Lutta S (2014) Assessment of selected heavy metal concentrations in selected fresh fruits in Eldoret Town, Kenya. J Environ Earth Sci 4:1-8

Mekassa B, Chandravanshi BS (2015) Levels of selected essential and nonessential metals in seeds of korarima (Aframomum corrorima) cultivated in Ethiopia. Braz J Food Technol 18:102-111

Miller JN, Miller JC (2005) Statistics and chemometrics for analytical chemistry. Pearson Education Limited, England

Miller-Ihli NI (1996) Atomic absorption and atomic emission spectrometry for the determination of the trace element content of selected fruits consumed in the United States.J Food Compos Anal 9:301-311

Mitchell GE, McLauchlan RL, Isaacs AR, Williams DJ, Nottingham SM (1992) Effect of low dose irradiation on composition of tropical fruits and vegetables. J Food Comp Anal 5:291-311

Nigussie K, Chandravanshi BS, Wondimu T (2010) Correlation among trace metals in tilapia (Oreochromis niloticus), sediment and water samples of lakes Awassa and Ziway, Ethiopia. Int J Biol Chem Sci 4:1641-1656
Paul DK, Shaha RK (2004) Nutrient, vitamins and minerals content in common citrus fruits in the Northern region of Bangladesh. Pak J Biol Sci 7:238-242

Sanchez-Castillo CP, Dewey PJ, Aguirre A, Lara JJ, Vaca R, Lean de la Barra P, Ortiz M, Escamilla I, Philip T (1998) The mineral content of Mexican fruits and vegetables. J Food Compos Anal 11:340-356

Seifu GM (2003) Status of commercial fruit production in Ethiopia. Ethiopian Agricultural Research Organization, Addis Ababa

Sertse S, Taye B (2000) Procedures for soil and plant analysis. National Soil Research Centre, Ethiopian Agricultural Research Organization, Addis Ababa

Simpkins WA, Louie H, Wu M, Harrison M, Goldberg D (2000) Trace elements in Australian orange juice and other products. Food Chem 71:423-433

Storey S, Treeby MT (2000) Seasonal changes in nutrient concentrations of navel orange fruit. Sci Hort 84:67-82

Tan KH (1996) Soil sampling preparation and analysis. Marcel Dekker, New York

Tokaliouglu S, Kartal S, Bïrol G (2003) Application of a three-stage sequential extraction procedure for the determination of extractable metal contents in highway soils. Turk J Chem 27:333-346

Townshend A (ed) (1995) Encyclopedia of analytical science. Academic Press, London

UHIS (The Universal Health Insurance Scheme) (2001) Natural food-Fruit Vitamin C Content. http//: www.naturalhub.com/natural_food_guide_ fruit_vitamin_c.htm Accessed Feb 2016

University of Florida (2005) IFAS Extenstion. http://nutrients.ffas.ufl.edu/nutrient\%20pages/BSFpages/SoilTriangle.htm Accessed June 2015

Van Loon JC (1985) Selected methods of trace metal analysis: biological and environmental samples. Wiley, New York

Wagesho Y, Chandravanshi BS (2015) Levels of essential and non-essential metals in ginger (Zingiber officinale) cultivated in Ethiopia. SpringerPlus 4:107. doi:10.1186/s40064-015-0899-5

Wall MM (2006) Ascorbic acid, vitamin A, and mineral composition of banana (Musa sp.) and papaya (Carica papaya) cultivars grown in Hawaii. J Food Comp Anal 19:434-445

Weldegebriel Y, Chandravanshi BS, Wondimu T (2012) Concentration levels of metals in vegetables grown in soils irrigated with river water in Addis Ababa, Ethiopia. Ecotoxicol Environ Saf 77:57-63

Yemane M, Chandravanshi BS, Wondimu T (2008) Levels of essential and nonessential metals in leaves of the tea plant (Camellia sinensis L.) and soils of Wushwush farms, Ethiopia. Food Chem 107:1236-1243

\section{Submit your manuscript to a SpringerOpen ${ }^{\circ}$ journal and benefit from:}

- Convenient online submission

- Rigorous peer review

- Immediate publication on acceptance

- Open access: articles freely available online

- High visibility within the field

- Retaining the copyright to your article

Submit your next manuscript at $\boldsymbol{\nabla}$ springeropen.com 